was one mentioned by myself in an address given in October, 1908, and published in THE LANow' of Jan. 9th, 1909. It was under my care in the Great Northern Central Hospital in 1903, and was associated with audibility of the extra auricular systoles as well as with their reproducibility by the graphic method.

Dr. Ritchie recorded'a kigh rate of auricular pulsation still earlier ${ }^{2}$ in a case of ventricular bradycardia, but the auricular speed in that case followed the administration of atropin, and he refers in his last paper to another case published by the late Dr. G. A. Gibson. These observations were all made prior to those on the interesting and important case recorded by Dr. Herz and Dr. Goodhart in January, 1909, not in 1908, as stated in Dr. Hay's paper.

Dr. Ritchie mentions that in his atropised case ' of accelerated auricle no auricular sounds were heard. The audibility of the sounds in my case, which I described to the Asculapian Society on Dec 13th. 1908, as "jugular embryocardia," 2 was probably owing to the comparatively slow rate of the massed rhythmic auricular extra systoles, as I consider them to be, in spontaneous cases and to their force. The auriculo-ventricular ratio was as 2 to 1 . The higher the auricular rate and the more nearly the pulsations approach the impotence of auricular fibrillation, into which they may apparently at times pass, the less audible in all probability are the auricular sounds likely to be.

I am, Sir, yours faithfully, ALEXANDER MORISON.

Upper Berkeley-street, W., Oct. 6th, 1913.

\section{LOW-PRICED CLINICAL THERMOMETERS.}

\section{To the Editor of THE LANCET.}

SiR,-The variations in the readings of the thermometers lescribed by Dr. J. B. Cook in his letter in your issue of Oct. 4th are not necessarily indications of faulty instruments. It is possible to immerse a dozen quite reliable instruments in warm water and obtain as many different readings. In performing the test, among other precautions to be observed one should ascertain that the thermometers have been well "shaken down," that the water is maintained at a constant uniform temperature, and that the instruments do not touch the bottom or sides of the vessel. Of the many dozens of clinical thermometers examined here the percentage of rejections is very small indeed, and the greatest error observed has not exceeded one degree.

The price of $10 \mathrm{~s}$. $6 a$. per dozen cannot be described as cheap, for accurate $2 \mathrm{~min}$. and $\frac{1}{2}$ min. thermometers can be purchased from makers at far less than $10 \frac{1}{2} d$. each, while 1 min. thermometers fitted with a lens front and verified at Kew are obtainable at less than $2 s$. each. Dr. Cook does not state whether he ascertained the behaviour of the thermometers when used to take the temperature of the body. I am, Sir, yours faithfully.

$$
\text { F. A. Hocking, }
$$

Oct. 4th, 1913. Pharmaceutist to the London Hospital.

\section{DISTRIBUTION OF INSURED PERSONS UNDER THE CAPITATION SYSTEM.}

\section{To the Editor of THE LANCET.}

SrR, - In your report of the last meeting of the London Insurance Committee you mentioned that Mr. E. B. Turner rose to correct my statement as to the Manchester scheme. 1 have this morning received a letter from Dr. J. H. Taylor, of Salford, and with his permission I venture to ask you to print the following extrants from that letter :-

I notice that according to the B.M..T. supplement, p. 286, Mr. Turner says you were in error about the Manchester scheme. As a matter of fact, it is he who is altogether wrong. We have a panel in Mancheste and Salford in every sense of the word and as defined in Regulation 7 . All the doctors on the list had to sign an agreement conforming to the Act and Regulations and the conditions of the Parliamentary grant, and the Commissioners refer to us as the panel. It is quite true that the Local Medical Committees do not like the word panel, and so they use the word "list," but it is a sort of placebo which they use with a nod and a wink.

Again, Mr. Turner said that the Manchester Insurance Conmittee handed over the whole of the Medical Benefit Fund to the Local Medical Committee. If he meant exactly what he said it is another pions delusiun like the first, which be may have heard in Manchester.

1 Transactions of the Royal Society of Kdinburgh, 1905. 2 THE LA YCET, Jan. 2nd, 1909.
Your own statement was tar moro correct than his. What really happens is as follows, and I spoak with certainty here as a member of the Salford Insurance Committee appointed by the Commissioners. The system in Manchester is a cony of the Sulford system, and in neither case is a single farthing handed over to the Local Medical Committee. The whole Medical Benelit, Fund, that is $8 s$. $6 d$. per insure person (less a few contributions to persons receiving treatmen thromgh institutions and to persons making their own arrangements, who are very few in number), is divided up into three funds-13/17th going to the panel fund, $3 / 17$ ths to the drug fund, and $1 / 17$ th to the drug suspense fund. To the panel fund is then added $6 d$. per person for domiciliary treatment of tuberculosis, which forms the medical treatment pool out of which the doctors aro paid per attendance. The important point is that the whole of this pool is paid to the doctors, except that at each payment-on-account a very small sum has been kept in hand by the Insurance Committce, partly because number of the doctors neglect to send in their accounts in time and partly because it is impossible to tell beforehand the exact total for the year owing to the variation in the total number of the insured, and thus with payment-on-account in advance something must be kept in hand, but the amount is be kept in hand, but, the amount is quite insignilicant, and at the en of the year the full total will be distributed. In Salford only $£ 6$ was retained in hand on July 31st out of a total pool that will certainly be over $£ 28,000$ for the year. Practically, then, you wer quite correct in saving that the whole fund available for medical treatment of the whole of the insured is paid to the doctors. O course you know that the doctors have no lists as you have with you capitation system. We know nothing of the insured until they actually come to us for treatment, and they are allowed to go to any doctor changing from one doctor to another as they like, Regulation $18 \mathrm{not}$ being enforced. This, by the way, tends to increase the malingering because if one doctor refuses a certificate the person simply goes about till he can find some other doctor ready to give a certificate. It is somewhat farcical for Mr. Turner to say that the mone is handed over to th. Local Medical Committee. All that committee does is to scrutinise the doctors' bills, and it has the power, which is often used, to cut down any doctor's bill when his attendances have been above the average, as excessive attendances would, of course, unfairly deplete the pool. When the bills hare thus been checked they are sent to the clerk of the Insurance com thus been check they are sent to the clerk of the Insurance Committe, Who again checks them to see that none but insured person have been included, and the clerk then presents them to the Insurance Committee, which may pass them for payment. Of course, the Local Medical Committee has nothing to to with the drug fund. Up to the present the whole pool has only sufficed to pay the doctors about 60 pe cent. of their bills charged according to a scale of fees agreed on between the Insurance Committee and the Iocal Medical Committee but this small dividend is solely because of the large number of attendances, the insignilicant sum kept in hand by the Insurance Committee making no practical difference. Fou will see that on ou system we avoid your difficulty of mallotted funds, but we have what is to my mind a fal worse difficulty-namely, that payment by attenclance encourages each doctor to put in as many attendances as possible.

The matter is one of considerable importance, but Dr. Taylor has stated the case clearly, and I think no comment is needed to show that the misunderstanding as to the system of payment in Manchester was Mr. Turner's, not mine.

Oct. 8 th, 1913

I am, Sir, yours faithfully,

H. H. MILLS

\section{THE MEDALS OF THE INTERNATIONAL MEDICAL CONGRESS.}

To the Editor of THE LANCET.

SIR, - In the confusion of the Congress a box of Congress medals was lost. It may be that on this account some members of Congress or ladies may have failed to obtain them. If such persons will write to me the medals will be sent to them. I am, Sir, yours faithfully,

W. P. HERRINGHAM

40, Wimpole-street, W., Oct. 4th, 1913. Honorary General Secretary.

Medical Mayor. - Mr. R. Jones Evans M.R.C.S. Eng., L.R.C.P. Lond, has been appointed mayorelect for Pwllheli.

University of LoNdon : UnIVERSity COLLEGE.In connexion with the Faculty of Medical Sciences at Iniversity College, London, the following awards have been made :-Bucknill Scholarship (135 guineas) and First Medical Exhibition (55 guineas), divided equally between M. H. Oldershaw, of the Brighton Municipal Technical College and University College, London, and D. J. Thomas, of St. David's College School, Lampeter, and University College of Wales, Aberystwyth. W. Feldman, of the Central Foundation School and University College, London, is classed as second medical exhibitioner (without emoluments) Epsom Free Medical Scholarship: E. V. Corry.-The Goldsmid entrance exhibitions have been awarded as follows :-First exhibition: 'T' H. Somervell, Caius College, Cambridge. Second exhibition: J. Vincent Bates, Pembroke College, Cambridge Proxime accessit: G. Y Oliver, University College, London. 